Сніцаренко П. М., д.т.н., с.н.с.;

Саричев Ю. О., к.т.н., с.н.с.

Центр воєнно-стратегічних досліджень Національного університету оборони України імені Івана Черняхівського, Київ

\title{
Методологічний підхід до створення підсистеми виявлення та оцінки негативного інформаційно-психологічного впливу на особовий склад військ (сил) як складової системи протидії такому впливу
}

Резюме. Запропоновано методологічний підхід до створення підсистеми виявлення та оцінки негативного інформаційно-психологічного впливу на особовий склад військ (сил) як складової системи протидії такому впливу, для ефективного функціонування якої була розроблена та верифікована відповідна методика, що дозволяє кількісно оцінювати рівень негативного впливу 3 метою випереджувального адекватного реагування на нього.

Ключові слова: негативний інформаційно-психологічний вплив; система протидії; виявлення і оцінка; методика, верифікація; підсистема.

Постановка проблеми. Протидія негативному інформаційному впливу невід'ємна складова забезпечення інформаційної безпеки України, у тому числі у воєнній сфері. Особливої важливості для України ця обставина набула напередодні та в період агресії з боку Російської Федерації, коли гостро та відчутно проявилися наслідки негативного зовнішнього інформаційнопсихологічного впливу, зокрема, на особовий склад Збройних Сил України (далі ЗС України). Тому протидія такому впливу, в першу чергу в інтересах забезпечення високого рівня морально-психологічного стану ЗС України, є актуальним проблемним завданням першорядного значення, яке потребує невідкладного вирішення шляхом організації дієвої системи протидії.

Аналіз останніх досліджень i публікацій. Значна кількість опублікованих робіт за тематикою протидії негативному інформаційно-психологічного впливу, зокрема, на особовий склад військ (сил), інтегрується у підручнику щодо моральнопсихологічного забезпечення ЗС України [1]. Аналіз показує, що на сьогодні теорія протидії такому впливу обмежена на рівні концептуально-декларативних положень, a тому для практики $є$ недосконалою. У ній бракує чітких формальних методів і методик для кількісних оцінок певних аспектів цієї сфери, у тому числі щодо виявлення та оцінки рівня негативного інформаційнопсихологічного впливу на особовий склад ЗС України. 3 цієї причини його кількісна оцінка не проводиться, а оцінка морально- психологічного стану ЗС України, який $€$ наслідком, зокрема, i такого впливу, здійснюється за якісними показниками на основі результатів моніторингу у військових частинах $\mathrm{i}$ підрозділах відповідно діючих інструкцій [2], тобто постфактум до наслідків різних впливів. Зазначене не дозволяс проводити випереджувальні заходи для стабілізації морально-психологічного стану військ (сил).

Метою статті $є$ розгляд методологічного підходу до створення підсистеми виявлення та оцінки рівня негативного інформаційнопсихологічного впливу на особовий склад 3С України на основі кількісних показників як необхідної умови створення перспективної системи протидії такому впливу iз властивостями реалізації дій випереджувального характеру.

Викладення основного матеріалу. Наукові положення методологічного підходу до створення підсистеми виявлення та оцінки рівня негативного інформаційнопсихологічного впливу на особовий склад $3 \mathrm{C}$ України на основі кількісних показників розроблено в ході виконання планових досліджень, які проведено у 2013 - 2017 роках. Основна сутність такого підходу полягає в наступному.

Ефективна протидія негативному інформаційно-психологічному впливу, зокрема, на особовий склад військ (сил), може бути лише за умов визначення (вибору) показника ефективності, яким у подальшому слід управляти шляхом відповідного впливу. Таким очевидним показником ефективності протидії слід вважати рівень морально-психологічного 
стану 3С України. У цьому випадку отримуємо необхідність створення системи соціального управління, де об'єктом управління $\epsilon$ рівень морально-психологічного стану ЗС України.

Важливо забезпечити стійкість зазначеного управління. За законами кібернетики

стійкість

управління забезпечується наявністю так званих "прямого" і “зворотного” зв’ язків. Тому, зважаючи на це, запропоновано загальну кібернетичну схему (модель) такого соціального управління, що матиме вигляд, як представлено на рис. 1.

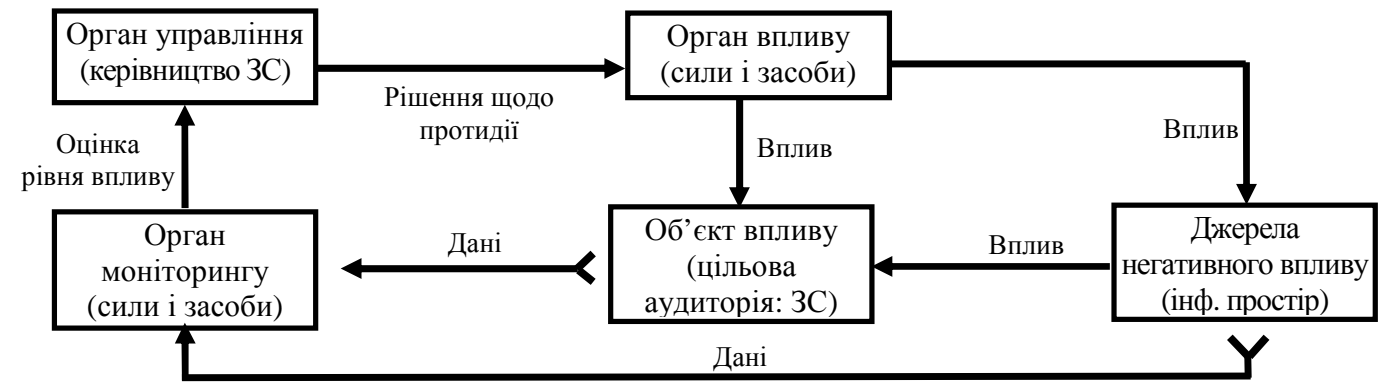

Рис. 1. Кібернетична модель реалізації протидії негативному інформаційно-психологічному впливу на особовий склад військ (сил)

Наведена модель може найбільш повно забезпечити активну протидію негативному інформаційно-психологічному впливу на особовий склад військ (сил) 3 такими ऑii обов'язковими фазами:

виявлення впливу;

оцінка рівня впливу;

формування висновків із оцінки рівня впливу та рішення щодо необхідності протидії;

планування заходів протидії впливу, затвердження плану заходів протидії;

реалізація заходів протидії впливу відповідно до плану;

контроль дієвості реалізованих заходів протидії впливу та їх коригування.

На практиці ця модель для 3С України частково реалізується, але лише в межах контура, обмеженого штриховою лінією. Як зазначено, цього недостатньо для здійснення випереджувальних стабілізаційних заходів, оскільки оцінка морально-психологічного стану 3С України, який $\epsilon$ індикатором сукупного інформаційного впливу на цільові аудиторії, що вже відбувся, здійснюється за його наслідками, отже без аналізу динаміки такого впливу, особливо негативного, джерелом якого $є$ інформаційний простір. Цей недолік діючої сьогодні системи необхідно компенсувати шляхом цілеспрямованого моніторингу подій в інформаційному просторі України, які можуть призвести до нанесення гуманітарної шкоди.

3 метою вирішення завдання створення умов для випереджувальних стабілізаційних заходів та реалізації моделі (рис. 1) у повному обсязі пропонується наступний методологічний підхід, в основі якого принцип кількісного оцінювання рівня негативного інформаційнопсихологічного впливу, для чого:

1. Запровадити в системі протидії негативному інформаційно-психологічному впливу на особовий склад 3С України практику реагування на основі кількісних критеріїв оцінювання рівня такого впливу.

2. Для виявлення та оцінки рівня негативного інформаційно-психологічного впливу на особовий склад військ (сил) в загальній системі протидії створити трьохрівневу підсистему моніторингу інформаційних процесів в інформаційному просторі держави, яка зображена на рис. 2.

В цій підсистемі моніторингу:

перший рівень - операторний (індикації інформаційних процесів за визначеними джерелами можливого впливу);

другий рівень - узагальнення даних першого рівня за класифікаційними ознаками, вагова обробка отриманої інформації;

третій рівень - виявлення факту негативного інформаційно-психологічного впливу та оцінки його рівня за інформацією другого рівня.

3. Впровадити в підсистему моніторингу методику виявлення та оцінювання у кількісному вимірі рівня негативного інформаційно-психологічного впливу на особовий склад військ (сил) 3 квантуванням за ступенем його значення для моральнопсихологічного стану ЗС України.

4. Кожному квантовому рівню інформаційно-психологічного впливу на особовий склад військ (сил) має відповідати певна сукупність компенсаційних заходів протидії відповідно кібернетичної моделі (на рис. 1) 3 метою стабілізації морально-психологічного стану визначеної цільової аудиторії, загалом ЗС України. 


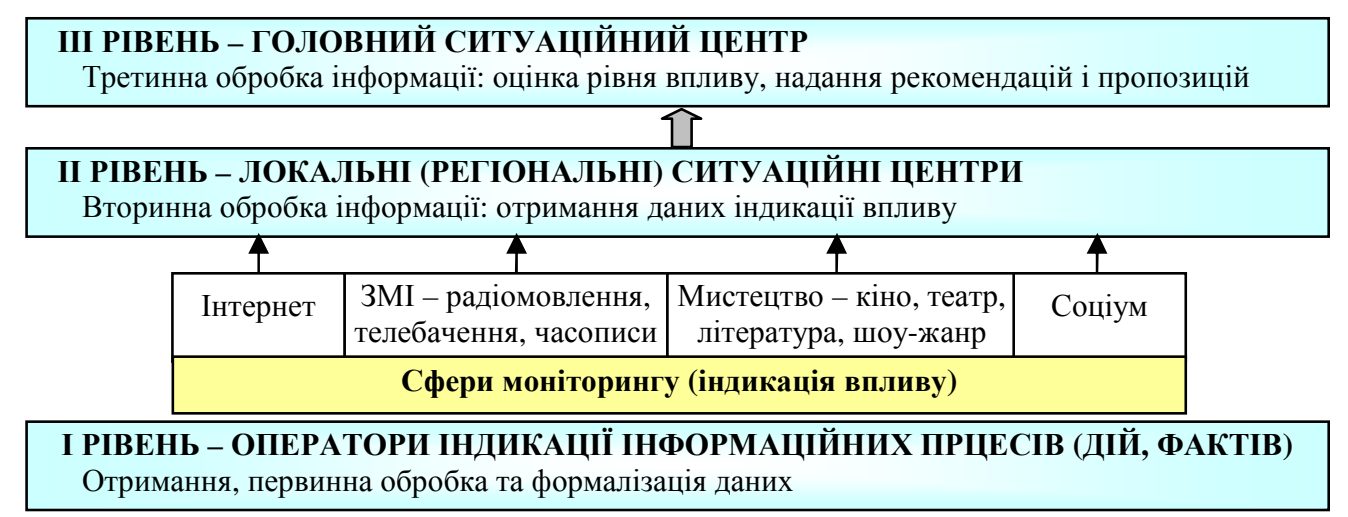

Рис. 2. Трирівнева підсистема моніторингу інформаційних процесів в інформаційному просторі держави

Одним із підходів до оцінки негативного впливу та розробки відповідної методики оцінювання може бути такий, де характеристикою (показником) дії загального деструктивного інформаційного процесу по відношенню до певної цільової аудиторії (особового складу 3С України) вважається рівень його інтенсивності, тобто міра дії процесу в одиницю часу

Інтенсивність $\chi=\frac{\text { Miра діï прощесу }}{\Delta T}$.

Зазначене одночасно $\epsilon$ інтегральним показником як оцінки рівня негативного впливу, так і індикатором виявлення такого впливу за величиною (значенням) його рівня.
Можна стверджувати, що значення показника інтенсивності $\chi$ за деякий період часу $\Delta T$ може приймати певні значення - від мінімальних і вище. Тоді динаміку ескалації інтенсивності загального деструктивного інформаційного процесу в інформаційному просторі держави за час $\Delta T$ по відношенню до особового складу військ (сил) можна умовно представити ступінчатою функцією рівнів, які слід вважати частковими показниками впливу, як це показано на рис. 3. При цьому, переходу на кожен із рівнів доцільно поставити у відповідність певний критерій за шкалою оцінок $\chi: \chi_{1}, \ldots, \chi_{5}$.

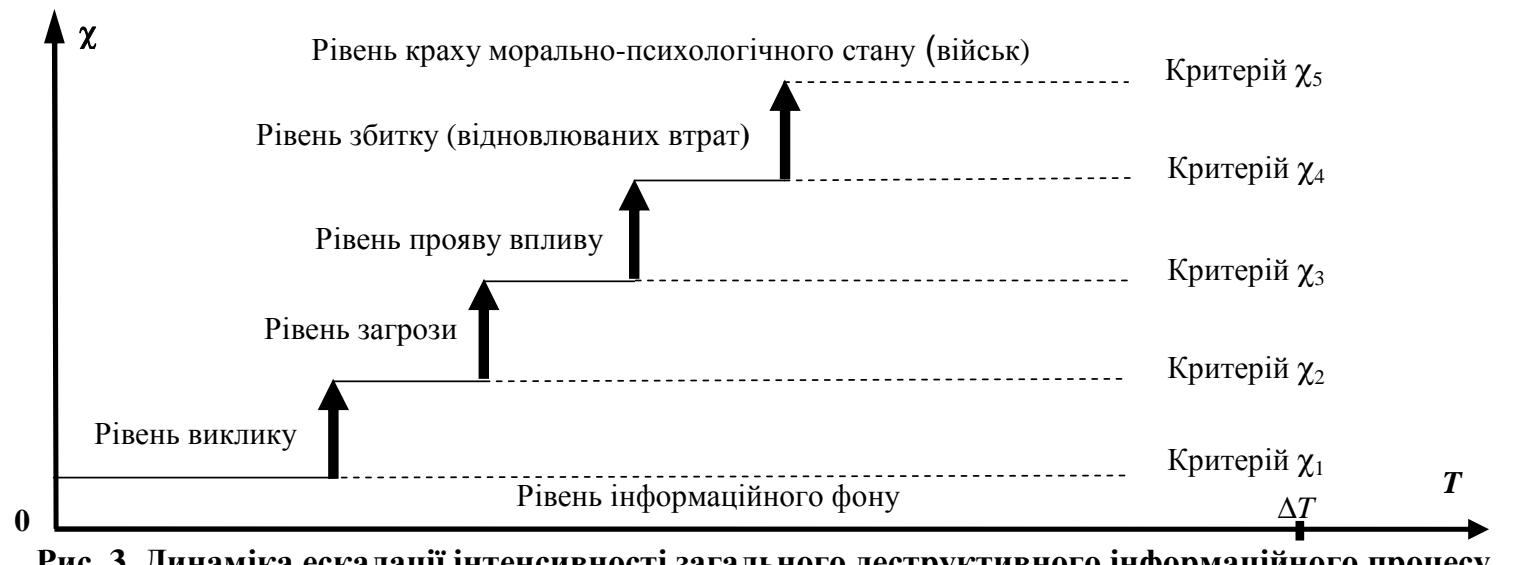

Рис. 3. Динаміка ескалації інтенсивності загального деструктивного інформаційного процесу

Запропоновані шість умовних якісних станів (часткових показників) загального деструктивного інформаційного процесу в інформаційному просторі держави та відповідні критерії, які можуть бути застосовані для визначення рівня його інтенсивності як міри впливу, зокрема, на особовий склад військ (сил) мають такі визначення:

рівень інформамійного фону - це практична відсутність за фіксований час $\square T$ спостереження інформаційних процесів (дій, фактів) в інформаційному просторі держави, що можуть мати негативний (підривний, руйнівний) характер по відношенню до особового складу військ; рівень виклику - кількість та змістовність інформаційних процесів (дій, фактів) за час $\square T$, виявлених в інформаційному просторі держави, які потенційно (за певних умов) можуть створити інформаційнопсихологічну загрозу особовому складу військ; рівень інформачійно-психологічної загрози - кількість цілеспрямованих деструктивних інформаційних процесів (дій, фактів) за час $\square T$, виявлених в інформаційному 
просторі держави, результатом чого може статися зниження рівня моральнопсихологічного стану особового складу військ;

\begin{tabular}{ccr}
\multicolumn{1}{c}{ рівень } & прояву & інформаційно- \\
психологічного & впливу & - \\
цілеспрямованих & & келькість
\end{tabular}
інформаційних процесів (дій, фактів) за час $\square T$, виявлених в інформаційному просторі держави, результатом чого є ознаки зниження рівня морально-психологічного стану особового складу військ;

рівень збитку (відновлюваних втрат) кількість цілеспрямованих деструктивних інформаційних процесів (дій, фактів) за час $\square T$, виявлених в інформаційному просторі держави, результатом чого $\epsilon$ зниження рівня морально-психологічного стану особового складу військ, яке може бути компенсоване наявними можливостями за час, достатній для ефективного виконання військами (силами) завдань за призначенням;

рівень краху морально-психологічного стану військ - кількість цілеспрямованих деструктивних інформаційних процесів (дій, фактів) за час $\square T, \quad$ виявлених в інформаційному просторі держави, результатом чого $\epsilon$ значне зниження рівня морально-психологічного стану особового складу військ, яке не може бути компенсоване наявними можливостями за час, достатній для ефективного виконання військами завдань за призначенням.

Шляхом реалізації процедур експертного опитування фахового середовища України та статистичної обробки отриманих даних визначено 22 класи та 17 підкласів інформаційних процесів (дій, фактів), які можуть негативно впливати на свідомість військовослужбовців і, відповідно, моральнопсихологічний стан особового складу $3 \mathrm{C}$ України, а також встановлено середнє значення "ваги" кожного класу (підкласу) на шкалі від 0 до 100 .

На основі отриманої статистики усіх інформаційних процесів (дій, фактів) на протязі часу $\Delta T=1$ рік також експертним методом отримано критерії знаходження рівня негативного інформаційно-психологічного впливу на шкалі “зваженоі” інтенсивності у перерахунку їх сумарної дії:

критерій $\chi_{1}=200 \times 10^{3}$ балів; критерій $\chi_{2}=350 \times 10^{3}$ балів; критерій $\chi_{3}=650 \times 10^{3}$ балів; критерій $\chi_{4}=900 \times 10^{3}$ балів; критерій $\chi_{5}=1400 \times 10^{3}$ балів.

Ці критерії стали основою для реалізації методики виявлення та оцінки інформаційнопсихологічного впливу на особовий склад військ (сил), яка діє на принципі масштабування у часі (відносно базового терміну $\Delta T=1$ рік) “зваженої" суми балів, отриманої 3 причини появи в інформаційному просторі держави певної кількості класифікованих інформаційних процесів (дій, фактів) за значно менший $s$-й термін $\Delta t_{s}<<T=1$ рік, наприклад, за місяць чи тиждень. При цьому застосовується алгоритм за формулою:

$$
\chi_{s}=\chi \frac{\Delta T}{\Delta t_{s}}
$$

де інтенсивність $\chi$ обчислюється за період $\Delta t_{s}<<\Delta$.

Наприклад, якщо за $\Delta t_{s}=1$ тиждень (7 днів) нараховане сумарне число балів 3000, то, застосувавши формулу (1), отримаємо:

$$
\chi_{s}=3000 \times 365 / 7 \approx 156,5 \times 10^{3} \text { (балів). }
$$

Таке число балів свідчить, що рівень негативного інформаційно-психологічного впливу знаходиться в межах інформаційного фону і фактично не впливає на зниження вже досягнутого морально-психологічного стану особового складу військ (сил), а отже зусилля для відповідної протидії є недоцільними.

Якщо ж за $\Delta t_{s}=1$ тиждень нараховане число балів, скажімо 13500, то, застосувавши формулу (1), отримаємо:

$$
\chi_{s}=13500 \times 365 / 7 \approx 704 \times 10^{3} \text { (балів). }
$$

У цьому випадку число балів свідчить, що рівень негативного інформаційнопсихологічного впливу знаходиться в межах прояву впливу, за якого попередньо досягнутий морально-психологічний стан особового складу збройних сил починає знижуватися. Слід зауважити, що лише у цьому діапазоні значень показника $\chi_{s}$ можна вести мову про виявлення власне негативного впливу (за ознаками незначного зниження моральнопсихологічного стану військ). Очевидно, що при цьому вже мають бути застосовані відповідні заходи протидії за схемою на рис. 1.

Останній приклад дуже показовий 3 позиції розуміння факту виявлення негативного інформаційно-психологічного впливу - таке виявлення фіксується не за окремими подіями в інформаційному просторі держави, а за їх інтегральною дією на особовий склад збройних сил, тобто коли їx інтенсивність за певний відносно невеликий проміжок часу $\Delta t_{s}$ стає відчутною для зниження морально-психологічного стану військ (сил).

3 метою перевірки дієздатності та 
адекватності методики виявлення i оцінки негативного інформаційно-психологічного впливу на особовий склад військ (сил) проведено iï верифікацію, яка здійснювалася в два етапи:

Eman 1 (статистично-розрахунковий) - в ході його проведення базовим інструментом була формула (1), у якій $\Delta T=1$ рік (365 днів), $\Delta t_{s}$ - період (кількість днів) накопичення статистичного матеріалу (подій, фактів в інформаційному просторі України, що можуть негативно впливати на особовий склад 3С України за даними різних інформаційних джерел, переважно друковані та електронні 3MI, радіо- та телепрограми) - 3 позиції раціональності взято 91 день (квартал року) та обчислено чотири “зрізи” критеріальної оцінки рівня впливу за календарний рік (щоквартально), при цьому усього оброблено близько 150 тис. повідомлень, із яких $8-10 \%$ реально могли негативно впливати на війська (сили);

Eman 2 (якісно-порівняльний)

отриманий на першому етапі результат критеріальної оцінки рівня негативного інформаційно-психологічного впливу порівнювався із якісною оцінкою реального морально-психологічного стану ЗС України за інформацією від Головного управління морально-психологічного забезпечення 3С України, яка одержується шляхом оцінювання відповідно до діючих інструктивних документів. За результатом порівняння приймалося рішення щодо рівня адекватності, а отже дієздатності, розробленої методики.

Результатом верифікаційного етапу $1 \epsilon$ узагальнені, окремо за кожен квартал 2016 року, дані спостереження за інформаційними подіями в інформаційному просторі України, які могли негативно вплинути на морально-психологічний стан особового складу ЗС України, з урахуванням їх вагового значення.

Загальна сума балів за I квартал склала 188692, за II квартал - 223311, за III квартал 234481, а за IV квартал - 238867, що свідчить про деяке збільшення інформаційного тиску на свідомість особового складу ЗС України $(\approx 25 \%$ упродовж року).

Застосувавши формулу (1) стосовно отриманих балів за кожен квартал окремо, отримаємо “зважену” інтенсивність загального деструктивного інформаційного процесу за кожен квартал у перерахунку на $\Delta T=1$ рік:

$\chi_{\mathrm{I}}=188692 \times 365 / 91 \approx 756 \times 10^{3}$ балів;

$\chi_{\mathrm{II}}=223311 \times 365 / 91 \approx 896 \times 10^{3}$ балів;

$\chi_{\text {III }}=234481 \times 365 / 91 \approx 938 \times 10^{3}$ балів;

$\chi_{\mathrm{IV}}=238867 \times 365 / 91 \approx 955 \times 10^{3}$ балів.

Перенісши ці дані на шкалу “зваженої" інтенсивності, отримаємо щоквартальні індикатори негативного інформаційнопсихологічного впливу на особовий склад 3С України, як зображено на рис. 4.

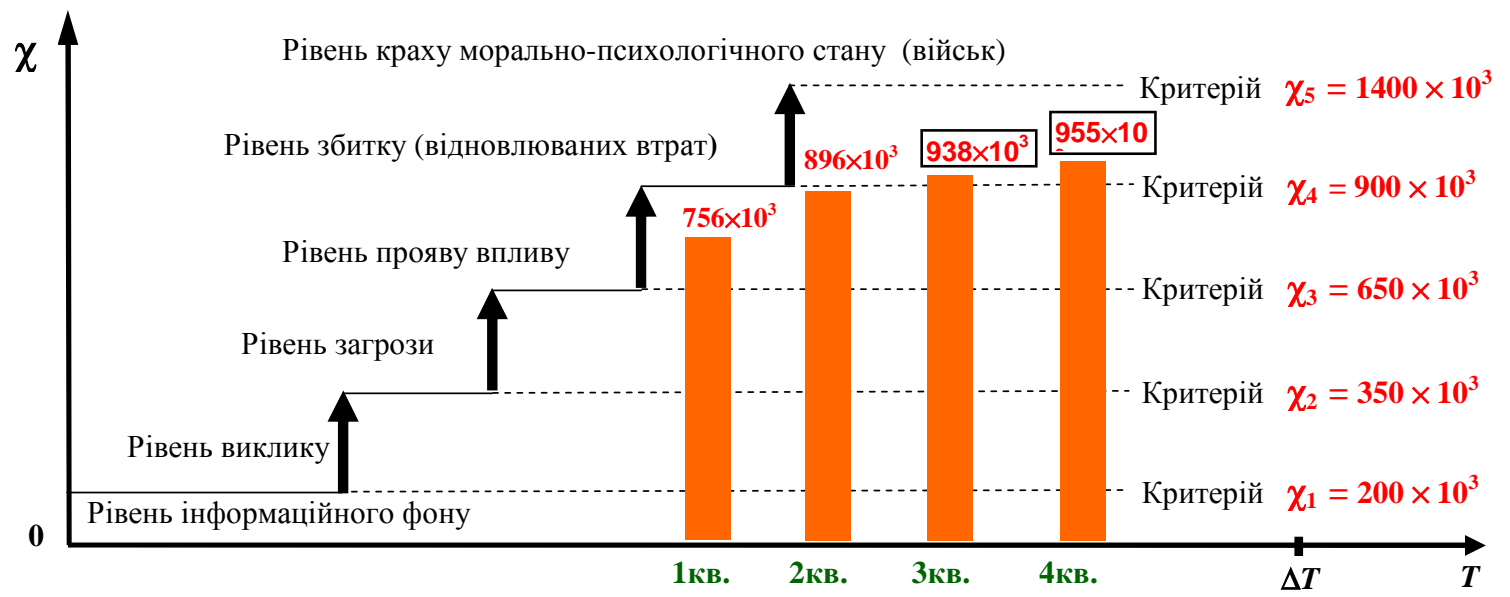

Рис. 4. Індикатори негативного інформаційно-психологічного впливу на особовий склад 3С України за I -IV квартали 2016 року

Отже, за інформаційними подіями в інформаційному просторі України у 2016 році спостерігається приблизно однакова картина, оскільки оцінена ситуація балансує на межі четвертого рівня - “прояв негативного інформаційно-психологічного впливу” та п'ятого рівня - "збитку (відновлюваних втрат)", причому із тенденцією збільшення рівня. Така індикація свідчить, по-перше, про факт реального впливу, тобто про його виявлення, а по-друге, про його кількісний та якісний виміри, тобто про його рівень, зокрема, у кожному кварталі 2016 року.

Аналіз змісту повідомлень засвідчив, що домінуючий негативний інформаційний процес в інформаційному просторі України для впливу на особовий склад 3С України створили російські та окремі національні 3МI у різних технічних формах прояву за класифікаційними напрямами “послаблення готовності ЗС України до оборони 
держави” та “погіршення іміджу 3С України i військової служби”.

У ході виконання верифікаційного етапу 2 за офіційним запитом якісну оцінку моральнопсихологічного стану особового складу ЗС України за 2016 рік надано Головним управлінням морально-психологічного забезпечення ЗС України [3, 4]. Сутність цієї оцінки полягає у такому.

Впродовж 2016 року моральнопсихологічний стан особового складу військових частин та органів військового управління ЗС України оцінюеться $я к$ задовільний та такий, що забезпечує виконання завдань за призначенням.

Водночас, негативний вплив на моральнопсихологічний стан особового складу мали наступні фактори:

розповсюдження через мережу Інтернет Російською Федерацією, засобами масової інформації негативної інформації про обстріли мирного населення підрозділами 3С України;

дискредитація дій керівництва країни та

3С України щодо спроможності приймати необхідні рішення для стабілізації ситуації; маніпулювання інформацією про терміни проведення мобілізації (демобілізації); несвоєчасне доведення

військовослужбовців командирами та начальниками достовірної інформації про рішення керівництва країни та ЗС України щодо вирішення проблемних питань.

Як видно із наведеної оцінки, яка $\epsilon$ незалежною від результатів дослідження із застосуванням розробленої методики, домінанти негативного впливу на особовий склад ЗС України за змістом у обох випадках $\epsilon$ близькими. Це означає, що обидві оцінки можливо порівнювати між собою.

По-перше, оцінка моральнопсихологічного стану особового складу ЗС України з боку Головного управління моральнопсихологічного забезпечення $3 \mathrm{C}$ України свідчить про наявність факту негативного інформаційно-психологічного впливу на військовослужбовців, як і індикатори відповідно до методики, що верифікується. Зазначене $\epsilon$ першою ознакою адекватності розробленої методики.

По-друге, висновок Головного управління морально-психологічного забезпечення $3 \mathrm{C}$ України, що “морально-психологічний стан ЗС України оцінюється як задовільний та такий, що забезпечує виконання завдань за призначенням" свідчить про те, що негативний інформаційнопсихологічний вплив у 3 С України відчувається $\mathrm{i}$, очевидно, наносить збитки моральнопсихологічному стану військовослужбовців. Про це об' єктивно свідчить ряд негативних фактів в лавах ЗС України, особливо у зоні проведення антитерористичної операції (АТО) на Сході держави, на що, зокрема, вказував Головний військовий прокурор України [5]. Зрозуміло також, що такий вплив та нанесені ним збитки системою відповідних заходів компенсуються, оскільки ЗС України зберігають здатність виконувати завдання за призначенням. Зазначена якісна оцінка означає, що сукупний негативний інформаційно-психологічний вплив на військовослужбовців має той наслідок (іншими словами - рівень), що морально-психологічний стан ЗС України знаходиться, орієнтовно, на рівні певного збитку (відновлюваних втрат), тобто на п’ятому критеріальному рівні, який визначено розробленою методикою.

По-третє, із порівняння цієї якісної оцінки 3 результатами кількісно-якісної оцінки, які отримано за розробленою методикою (рис. 4), видно, що обидві оцінки у проекції на моральнопсихологічний стан особового складу ЗС України, який за своєю сутністю спричиняється інформаційним впливом на свідомість військовослужбовців (позитивним та негативним), за обома методичними підходами практично збігаються, а його нинішній реальний стан визначився, зокрема, інтенсивністю негативних інформаційних подій в інформаційному просторі України упродовж року, спрямованих на особовий склад ЗС України. 3 цієї причини можна стверджувати, що отримана за допомогою розробленої методики кількісно-якісна оцінка загалом відповідає інформаційному процесу, що $\epsilon$ другою й найважливішою ознакою адекватності методики.

Наведеними результатами порівняння попередньо підтверджена адекватність, а отже і дієздатність, методики виявлення та оцінки рівня негативного інформаційно-психологічного впливу на особовий склад військ (сил) на прикладі діяльності ЗС України.

\section{Висновки.}

1. Невід'ємною ланкою системи протидії негативному інформаційно-психологічному впливу на особовий склад військ (сил), зокрема 3С України загалом, яка повинна діяти за кібернетичним принципом, має бути підсистема виявлення та оцінки рівня такого впливу, що функціонуватиме на основі відповідної методичної бази.

2. Головним методологічним принципом функціонування підсистеми виявлення та оцінки рівня негативного інформаційнопсихологічному впливу на особовий склад військ (сил) має бути принцип застосування кількісної міри при виявленні та оцінці рівня такого впливу, що забезпечить слідкування за його динамікою та реалізацію випереджувальної стратегії у кібернетичній моделі протидії.

3. Перспективним елементом для 
створення такої підсистеми у складі загальної системи протидії, зокрема в інтересах 3С України, може стати розроблена методика виявлення i оцінки рівня негативного інформаційно-психологічного впливу на особовий склад військ (сил), яка пройшла первинну фазу верифікації, у ході якої попередньо підтверджена іiі адекватність та дієздатність.

4. Основними суб' єктами забезпечення реалізації кібернетичної моделі системи протидії та, відповідно, впровадження розробленої методики, в інтересах 3С України $є$ профільні структурні підрозділи МО України та ЗС України: ГУР МО України, УІТ МО України, ДВОН СГП МО України, УКП МО України, ООШ ЗС України (ЦІП), ГОУ ГШ ЗС України, ГУ МПЗ ЗС України, ССпО ЗС України, ГУЗІС ГШ ЗС України, ЦУ РЕБ ГУОЗ ЗС України.

5. Попередній характер оцінки щодо адекватності та дієздатності розробленої методики виявлення і оцінки рівня негативного інформаційно-психологічного впливу на особовий склад військ (сил) потребує продовження досліджень в процесі практичного впровадження в інтересах уточнення рівня іiі адекватності та дієздатності.
Подальші зосередити на дослідження доцільно науковому супроводженні впровадження зазначеної методики на прикладі діяльності 3С України, а також іiї коригуванні за необхідності з урахуванням результатів дослідної експлуатації.

\section{ПЕРЕЛІК ВИКОРИСТАНОЇ ЛІТЕРАТУРИ}

1. Морально-психологічне забезпечення у Збройних Силах України: підручник у 2-х ч. Ч.1. / [В. М. Вілко, В. М. Грицюк, В. Г. Дикун та ін.] за заг. ред. В. В. Стасюка. - К.: НУОУ, 2012. - 464 с.

2. Інструкція про порядок оцінки морально-психологічного стану в Міністерстві оборони України та Збройних Силах України (затверджено наказом МО України від 21.05.2013 № 335, зі змінами, внесеними наказом МО України від 17.12.2015 № 728, зареєстровано в Мін’юсті України 11.01.2016 № 29/28159).

3. Лист начальника Головного управління моральнопсихологічного забезпечення (вих. № $354 / 1877$ від 26.07.2016 року).

4. Лист начальника Головного управління моральнопсихологічного забезпечення (вих. № 354/1438 від 07.04.2017 року).

5. Матіос А. В. Небойові втрати української армії за два роки проведення АТО. - [Електронний ресурс] /А. В. Матіос. - Режим доступу: http:// matios.info/uk/novini/nebojovi-vtraty-ukrayinskoyi-armiyi-zadva-roky-provedennya-ato.

Стаття надійшла до редакції 03.07.2017

\section{Сницаренко П. Н., Д.Т.н., с.н.с.;}

Сарычев Ю. А., к.т.н., с.н.с.

Центр военно-стратегических исследований Национального университета обороны Украины имени Ивана Черняховского, Киев

\section{Методологический подход к созданию подсистемы выявления и оценки негативного информационно-психологического влияния на личный состав войск (сил) как составной части системы противодействия такому влиянию}

Резюме. Предложен методологический подход к созданию подсистемы выявления и оценки негативного информационно-психологического влияния на личный состав войск (сил) как составной части системы противодействия такому влиянию, для эффективного функционирования которой была разработана и верифицирована соответствующая методика, позволяющая количественно оценивать уровень негативного влияния с целью опережающего адекватного реагирования на него.

Ключевые слова: негативное информационно-психологическое влияние; система противодействия; выявление и оценка; методика, верификация; подсистема

\section{P. Snitsarenko, Ds.T, senior researcher}

Y. Sarychev, Ph.D, senior researcher

Center for Military and Strategic Studies of the National Defence University of Ukraine named after Ivan Chernyhovsky, Kyiv

The methodological approach to the creation of the subsystem of eliciting and appraisal of negative information influence on the troops' personnel of (forces) as a component system of counteracting such influence

Resume. The methodological approach is offered for the creation of the subsystem of eliciting and appraisal of negative informatively psychological influence on the personnel of troops (forces) as a component system of counteraction such influence. The relevant method was developed and verified for the effective functioning the subsystem, which allows estimating quantitatively the level of negative influence with the purpose of proactive adequate reacting to it.

Keywords: negative information-psychological influence; system of counteraction; eliciting and appraisal; method, verification; subsystem. 